\section{RESEARCH ON MOBILE CONSUMER HABIT AND ATTITUDE TO- WARDS FEMTOCELL SERVICES}

\author{
Novika Candra Astuti ${ }^{1}$ and Lamhot S.P. Simamora² \\ ${ }^{1}$ Widyatama University \\ ${ }^{2} \mathrm{PT}$ Telekomunikasi Indonesia, Tbk. \\ ${ }^{1}$ Novika.candra@widyatama.ac.id 2simamora@telkom.co.id
}

JURNAL

MANAJEMEN

INDONESIA

Vol. 16 - No. 1

April 2016

\title{
Abstract
}

Femtocell is the new technology that may offer competitive value to mobile service providers for increasing their market share, retain the consumers and lower the operational cost in providing the better signal especially inside building (indoor). This study investigate the habit and attitude of mobile consumers in two specific areas in Bandung; Buah Batu Regency and Mitra Dago-Antapani, toward the use of femtocell value and services. This study also considers the marketing implicationsin the success of femtocell deployment in the future.

Keywords: Femtocell, habit, attitude

\section{Introduction}

Indonesia's telecommunicationindustry has grown with an exceptional rate in the last five years. The dynamic change in the market has put this industry as one of the highest competitive industry. In 2010 this industry is estimated at a value of 112 billion rupiahs with a growth rate of $11.2 \%$ over the 2009 . Like other countries, Indonesian telecommunicationn industry is also dominated by mobile service. The penetration rateof mobile service, which is now about $70 \%$ has far surpassed the fixed phone service. The telecommunication market in Indonesia has been opened to 11 mobile operators or service providers. As each operator promotes heavily in the market to increase the market share, price war is not inevitable and since 2008 Indonesia tariff has became one of the most cheapest in the world.

In this fierce competition situation, operators must create and offer distinc service to the market in order to increase their market share, retain their existing customerswhile also reduce the operational cost. One opportunity that can be offered by operators is related to the poor signal coverage inside the building (indoor) area, due to the propogation through walls, while it is been identified that about $70 \%$ of mobile services traffic happens indoor (Femto Forum, 2009).

Improving signal strength indoor has been a challenge for service providers. Most of them deploy an indoor macro antenna system that cost them a lot for space rent, electricity power, and maintenance. But now Femtocelloffer a promising solution for indoor signal and capacity problem with much lower cost. Femtocell is a small, low cost, low power access point, enabling to access to a network operated wireless network, located in user or private premises. Femtocell technology is growing significantly and today there are about 63 mobile operators commercialize this technology in the world (Femto Forum, 2010).This research proposes to find out the opportunity of Femtocellvalue and services in Indonesia market by understanding the consumers habits on using the mobile services indoor (home) and their attitude towardsthe Femtocell services.Some research questions has been developed for this study, namely:

1) Are there any differences in attitude among heavy, moderate, and light users toward mobile services?

2) Are there any differences in habit among heavy, moderate and light users when using mobile services?

3) What leading factors that drive consumer's interest in Femtocell?

4) Which Femtocell services are demanded by consumers?

5) How much money does the consumer want to pay for Femtocell service? 


\section{JURNAL}

MANAJEMEN

INDONESIA

Vol. 16 - No. 1

April 2016

Table 1

Mobile User Segmenta-

tion
6) Which segments will be the most profitable for Femtocell?

\section{Literature Review}

\subsection{Mobile Consumer Segmentation}

Market segmentation can be done in various ways. It is the way for grouping the market or consumer based upon similarities they share with respect to any dimensions we deem relevant to our business; whether it be consumer needs, consumerusage pattern, channel preferences, interest in certain product features, consumerprofitability, etc. In this study, based on usage pattern of mobile services, we segment the usersin three segments, as shown in Table 1 below.

\begin{tabular}{llll}
\hline \multicolumn{1}{c}{ Segment } & \multicolumn{1}{c}{ Voice Call Usage/day } & Data Access Usage/day & Expenditure/Month \\
\hline Heavy user & 4 times & 6 hours & Rp500.000 \\
Moderate user & $3-4$ times & $3-6$ hours & Rp250.000-Rp500.000 \\
Light user & $<3$ times & $<3$ hours & $<$ Rp250.000 \\
\hline
\end{tabular}

\subsection{Consumer Habits on Mobile Services Usage}

Habits are learned dispositions to repeat past responses. They are triggered by features of the context that have covaried frequently with past performance, including performance locations, preceding actions in a sequence, and particular people. Contexts activate habitual responses directly, without the mediation of goal states (Wood and Neal, 2007). Most notably, William James (1890) proposed that habits are triggered spontaneously by sensory cues and preceding actions, and that this cuing proceeds without recourse to goalrelated constructs of volition and will. In this study, habits of using the mobile service in the home are classified in to 8 (eight) categories:the calling time consumer make, the internet access time, places to make a call in the house, type of mobile services they use, problems in using the mobile services, and how they handle the problems of using the mobile services. Hence, based on the segmentation in this study, it is hypothesized that:

H1: There are differences in habit among heavy, moderate and light users when using mobile services

\subsection{Consumer Attitudes on Mobile Services Usage}

Attitude is populated to be the first antecedent of behavioral intention. It is an individual's positive or negative belief about performing a specific behavior. These beliefs are called behavioral beliefs. An individual will intend to perform a certain behavior when he or she evaluates it positively. Attitudes are determined by the individual's beliefs about the consequences of performing the behavior (behavioral beliefs), weighted by his or her evaluation of those consequences (outcome evaluations). Those attitudes are believed to have a direct effect on behavioral intention and are linked with subjective norm and perceived behavioral control (Ajzen, I., Fishbein, M. 1998).

In this study, the attitude towards mobile services is categorized in three aspects: belief, affect and behavior. Hence, based on the segmentation in this study, it is hypothesized that:

H2: There are differences in attitude among heavy, moderate and light users toward mobile services

\subsection{Femtocell Value and Services}

Femtocell is a small cellular base station meant to boost service quality and provide value added services within a home. It connects to the service provider's network via broadband (such as DSL or cable); current designs typically support 2 to 5 mobile phones in a residential setting. A Femtocell essentially routes mobile calls over the internet. A Femtocell allows service providers to extend service coverage indoors, especially where access would otherwise be limited or unavailable. This is true in many homes where wireless signal can- 
not reach inside or there is poor signal strength due to security or physical obstructions. One of the most significant advantages of Femtocell for the wireless operator is that by directing home mobile calls on the internet, operators can free up the wireless network. In emerging markets, wireless network congestion rates point to the idea that Femtocells would be a boon in such locations.

Femtocell offers value to the users like better indoor coverage, better quality of service indoor like video/audio streaming access, special femtocell tariffthat lower than the regular mobile tariff, faster internet access through mobile phone/mobile model, and longer life of mobile phone battery due to the strength mobile signal in the home area. Besides the access service offerings by femtocell, the study also examined consumers'preferences in a number ofnew services that can be accessed through femtocell, they are Family Alerts, Family Locator, Virtual Home Number, Music Sync, Photo Sync, Contact/Calendar Sync, Cell Phone Remote Control, and Home Reminders. Hence, based on the value and servicesit is hypothesized that:

\section{H3: Better signal strength in the home is the most demanding factor to have Femtocell}

H4: Family alerts is the most interesting Femtocell service for consumer

\subsection{Willingness to Pay (WTP)}

Different practical studies have shown that minor variations of prices and the corresponding consumer behavior can have notable effects on revenues and profits (Marn, et al., 2003). Companies often adopt some business rules and follow a strategy that could be denoted as "intuitive" pricing. Remarkably, such a behavior is not limited to retailing or service industries only, where mark-up-pricing is still representing the predominant practice (cf. Levy et al., 2004, Berman and Evans, 2001, p. 555 ff., Monroe, 2003, p. 257). Several recent studies indicate that only 8 to $15 \%$ of all companies develop pricing strategies based on likely buyer response behavior (Monroe and Cox, 2001). In contrast to what seems to be common practice, managers. p. 387) considers valid estimates of WTP essential for developing an optimal pricing strategy. Similar arguments about the importance of WTP and perceptions of value by customers can also be found by many other authors (cf. Monroe, 2003, pp. 11-12, Nagle and Holden, 2002, p. 7 and pp. 104-105, and Simon, 1992, p. $365 \mathrm{ff}$.). Such estimates can be used to forecast market response to price changes and for modeling demand functions. Furthermore, various approaches to measure brand equity (cf. e.g., Farquhar, 1989, Srivastava and Shocker, 1991, Park and Srinivasan, 1994) emphasize customers' WTP in terms of the (monetary) added value endowed by a brand to a specific product vis-à-vis its' competitors or an unbranded baseline product. Good overviews on contemporary approaches to brand equity measurement are presented by Sattler (1995) or Ailawadi et al. (2003). consider the knowledge of customers' responses to different prices as a cornerstone of marketingstrategies, particularly in the areas of product development, brand management, value audits, and competitive strategy (Anderson et al., 1993). Hence, it is hypothesized that:

H5: Consumer has a willingness to pay between Rp $100.000-R p 125.000$ for Femtocell benefit, and between $R p 20.000$ - Rp 25.000 for Femtocell service

H6: Heavy users are the most profitable segment for Femtocell

\section{Research Methodology}

\subsection{Operational Variables}

Table 2 shows about operational variables in this study including variable, sub-variable, indicator, and scale. Then, the data was analysed by using Cluster, Discriminant analysis, Factor Analysis, Multidimentional Scaling and Descriptive Statistics in SPSS 19.00. 


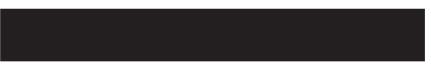

\section{JURNAL}

MANAJEMEN

INDONESIA

Vol. 16 - No. 1

April 2016

Table 2

Operational Variables

\begin{tabular}{|c|c|c|c|}
\hline Variable & Sub-Variable & Indicator & Scale \\
\hline Habit & $\begin{array}{l}\text { Usage time } \\
\text { Places to do phone call at } \\
\text { home } \\
\text { Mobile phone services } \\
\text { usage } \\
\text { Service complaints }\end{array}$ & $\begin{array}{l}\text { Usage time of phone call } \\
\text { Usage time of internet/data } \\
\text { access } \\
\text { Usage frequency level of } \\
\text { each place } \\
\text { Frequency level of each } \\
\text { complaint }\end{array}$ & Interval \\
\hline Attitude & Affects & $\begin{array}{l}\text { Loyalty } \\
\text { Operator/Service provider } \\
\text { Product/service belief } \\
\text { Advertising influence } \\
\text { Peer influence } \\
\text { Salesman influence } \\
\text { Purchase intention } \\
\text { Product value expression } \\
\text { Prior knowledge }\end{array}$ & 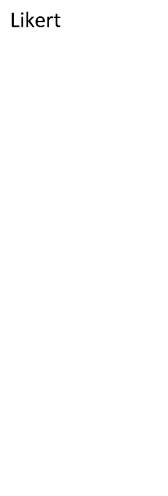 \\
\hline $\begin{array}{l}\text { Femtocell Value and } \\
\text { Service }\end{array}$ & 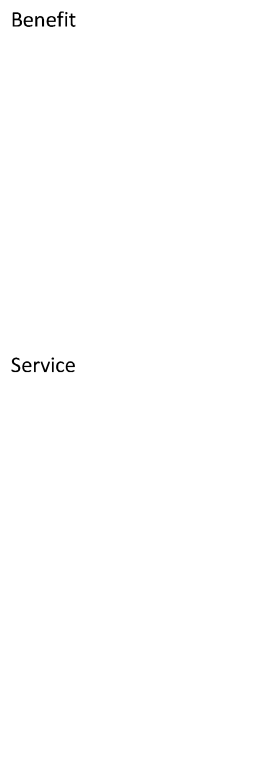 & $\begin{array}{l}\text { Signal strength } \\
\text { Faster video/audio } \\
\text { streaming } \\
\text { Cheaper call/data cost } \\
\text { Faster internet access using } \\
\text { handphone } \\
\text { Longer battery life } \\
\text { Family alerts } \\
\text { Virtual Home Number } \\
\text { Music Sync } \\
\text { Photo Sync } \\
\text { Contact/Calendar sync } \\
\text { Cell phone remote control } \\
\text { Family locator } \\
\text { Home reminders }\end{array}$ & $\begin{array}{l}\text { Likert } \\
\text { Ordinal (ranking) }\end{array}$ \\
\hline
\end{tabular}

\subsection{Population and Sample}

The population of this study is taken from two different areas, Buah Batu Regency and Mitra Dago-Antapani. Each area consists of 400 houses and 200 houses respectively. All the houses in these two areas are two-storey building. Using the Nomogram of Harry King (Sugiono, 2008), with error rate of 0.10 and confidence interval of 0.90 we calculated the sample size of 130 households and 60 households for Buah Batu and Mitra Dago respectively. The sample is taken by using judgmental sampling method. The questionnaires distribute to each area and leave to be filled by the family leader (usually the father). For some incomplete questionnaires, they will be returned to be completed by the respondents. Each respondent will be given a souvenir as a token of gratitude for their participation in this study.

\section{Results}

\subsection{Case-1: Buah Batu Regency, Bandung}

\subsubsection{Respondents Profile}

Most of the heads of the families' age in Buah Batu Regency are between 46-50 years old. The decision making in the family is mostly determined by Father (46\%). In some families, the decision is determined by the parents (37\%), all family members (15\%) and mother 
(2\%). The education level of the family head is ranging from only junior high school till doctoral degree, but most of them are undergraduate (58\%). Most of the family in Buah Batu Regency has two children (47\%). Some families have only one child (31\%), 3-children (12\%), and no-child (7\%).

\subsubsection{Reliability Test}

Reliability test is applied to ensure consistency in measurement across time and objects. The reliability measurement shows that the questionnaire is reliable to use. The Cronbach's Alpha( $\alpha)$ value for all items are bigger than 0.6. The result showed that value of Cronbach Alpha is 0,678 .

\subsubsection{Consumer Segmentation}

Consumer segmentation is determined by using cluster analysis that classifies user based on its common characteristics. By using K-Means Cluster analysis for income, telephone and internet access expenditure in amonth, average call in a day, and average internet access time in a day, then we get user segmentation within 3 clusters; Cluster- 1 as Heavy user, Cluster-2 as Light User, and Cluster-3 as Moderate User, as shown in Tabel 3 below.

\begin{tabular}{cccc}
\hline Variable & Cluster 1 & Cluster 2 & Cluster 3 (ModerateUser) \\
& (High User) & (Light User) & \\
\hline Income monthly & Rp 5,000,000- Rp & Rp 5,000,000-Rp & Rp 5,000,000-Rp 10,000,000 \\
& 10,000,000 & Rp250,000-Rp 500,000 & Rp 250,000-Rp 500,000 \\
$\begin{array}{c}\text { Household expenditure for } \\
\text { telephone and internet } \\
\text { access }\end{array}$ & Rp 500,500-Rp 750,000 & & \\
Average call a day & More than 4 times a day & 3 to 4 times a day & 3 to 4 times a day \\
Average internet access & 3 to 6 hours a day & 1 to 3 hours a day & 9 to 12 hours a day \\
\hline
\end{tabular}

\subsubsection{Consumer Habit and Attitude Towards Mobile Services}

In this study, the consumer habit is investigated by 8-categories; the calling time consumer make, the internet access time, places to make a call in the house, type of mobile services they use, problems in using the mobile services, and how they handle the problems faced in using the mobile services. The study shows that most consumer usually make a phone call between between $12: 00 \mathrm{pm}$ and 06:00pm (55.1\%) and between 06:00am and $12: 00 \mathrm{pm}(31 \%)$. For accessing the internet, most consumers do it between 06:00am and $12: 00 \mathrm{pm}(44 \%)$, and the others $33 \%$ do it between $12: 00 \mathrm{pm}$ and $06: 00 \mathrm{pm}$. Consumer often makes the call in the leisure room (40\%), family room (36\%), and living room (17\%).

Analysing the data with MANOVA by using Pillai procedure, Wilks' Lambda, Hotelling and Roy's, it is found that there are 4-habit variables significantly differ the habit of consumer in using mobile services (Sig. $<0.05$ ), they are about places to make a call (bedroom), type of mobile services usage (chatting, phonecall, , social networking and email), problems faced in using the mobile service (connected to a wrong number and internet access failure), handling the problem of a phone call (move to other place or spot, try it in another time, and stop making a call), handling the problem of SMS service (stop sending the SMS), and handling the problem of mobile internet service (stop accessing the internet).

So this analysis concludes that there are differences in habit among heavy, moderate and light users when using mobile services or in other way it supports the hypothesis (H1 is accepted). By using the same procedure, this study tests the attitude variables towards mobile services usage. The study finds that value expression and prior knowledge differ the attitude of consumers in using mobile services (Sig. $<0.05$ ). Therefore this analysis support the hypothesis ( $\mathrm{H} 2$ is accepted).
JURNAL

MANAJEMEN

INDONESIA

Vol. 16 - No. 1

April 2016

Table 3.

Buah Batu Regency

User Segmentation 


\subsubsection{Femtocell Value and Services}

\section{JURNAL}

MANAJEMEN

INDONESIA

Vol. 16 - No. 1

April 2016

Table 4

Factorial Analysis of

Femtocell Access Value
This study uses factor analysis method to investigate what factors influencing consumers to femtocell value and services. Considering the five values offered by femtocell, it indicates that faster internet access is the most strongest correlation factor $(0.879)$ for consumer to choose the femtocell access. Therefore this result does not support the hypothesis ( $\mathrm{H} 3$ is rejected) that states better signal strength in the home is the most demanding factor to have Femtocell.

\begin{tabular}{lc}
\hline Signal strength & 0.820 \\
\hline Faster video/audio streaming & 0.843 \\
Cheaper call/data cost & 0.838 \\
Faster internet access using handphone & 0.879 \\
Longer battery & 0.733 \\
\hline
\end{tabular}

In analyzing customer preferences towards Femtocell services, this study runs the dimensional analysis and it shows that Home Reminder and Family Locator are the most interesting femtocell service for consumer. Therefore this result does not support the hypothesis ( $\mathrm{H} 4$ is rejected) that states Family alerts as the most interesting Femtocell service for consumer.

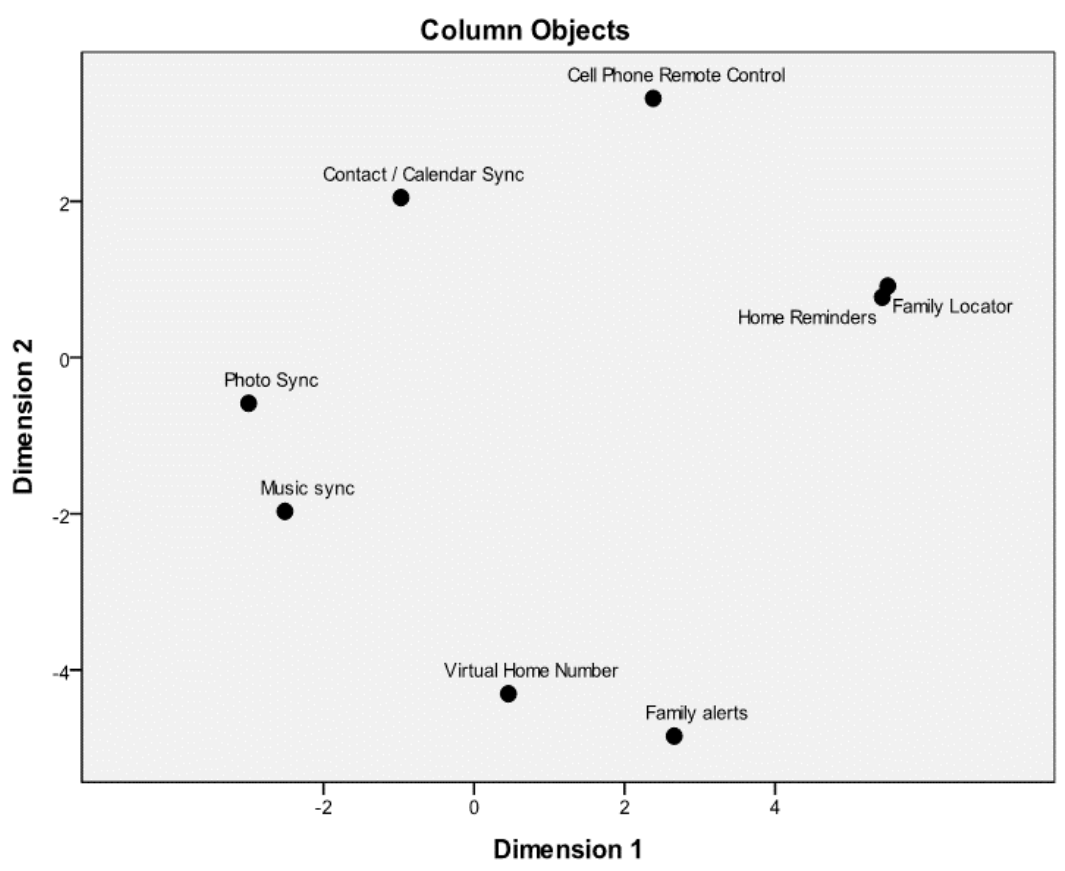

\subsubsection{Willingness to Pay for Femtocell Access and Services}

The descriptive analysis method in this study shows that most consumer (52\%) chooses the range of Rp50,000-Rp75,000 as the price for femtocell access. About $15 \%$ of consumers choose the range price of Rp100,000 to Rp125,000 as the price for femtocell access and only $7 \%$ choose more than Rp125,000 (see Table 5). 


\begin{tabular}{ccc}
\hline & Frequency & Percentage (\%) \\
\hline Rp 25,000-Rp 50,000 & 16 & 12 \\
$\operatorname{Rp~50,000-Rp~75,000~}$ & 70 & 52.6 \\
$\operatorname{Rp~} 75,000-\operatorname{Rp~100,000}$ & 18 & 13.5 \\
$\operatorname{Rp~100,000-Rp~125,000}$ & 20 & 15 \\
$\operatorname{Rp} 125,000$ & 9 & 6.8 \\
Total & 133 & 100 \\
\hline
\end{tabular}

Beside the femtocell access itself, this study also investigate the willingness to pay for each Femtocell service. Most consumer (55\%) choose the price range of Rp25,000 to Rp30,000 as the price for Femtocell service. There are about $29 \%$ of consumer choose the price above Rp30,000 for Femtocell service (see Table 6).Therefore this result does not support the hypothesis ( $\mathrm{H} 5$ is rejected) that states Consumer has a willingness to pay between Rp100,000 - Rp 125,000 for Femtocell access, and between Rp20,000 - Rp25,000 for Femtocell service.

\begin{tabular}{lcc}
\hline & Frequency & Percentage (\%) \\
\hline $\operatorname{Rp~15,000-Rp~20,000~}$ & 11 & 8.3 \\
$\operatorname{Rp~20,000-Rp~25,000}$ & 10 & 7.5 \\
$\operatorname{Rp~25,000-Rp~30,000~}$ & 73 & 54.9 \\
$\operatorname{Rp~30,000-Rp~35,000~}$ & 15 & 11.3 \\
$\operatorname{Rp~35,000-Rp~40,000~}$ & 15 & 11.3 \\
$>\operatorname{Rp~40,000}$ & 9 & 6.8 \\
\hline
\end{tabular}

\subsubsection{Potential Market Segment for Femtocell}

The potential market segment for Femtocell is investigated through the intention to buy of consumer with the previous Cluster analysis result. This study indicates that most of the consumer $(80 \%)$ is still uncertain about the Femtocell Value. Among the segments, Moderate user is the one who intents to have the femtocell servies in his/her house. Therefore this result does not support the hypothesis ( $\mathrm{H} 6$ is rejected) that states Heavy users are the most profitable segment for Femtocell.

\begin{tabular}{llll}
\hline & Heavy User & Light User & Moderate User \\
\hline Strongly agree to buy & 1 & & \\
Agree to buy & 6 & 10 & 11 \\
Doubt & 17 & 77 & 22 \\
Total & 24 & 87 & \\
\hline
\end{tabular}

\subsection{Case-2: Mitra Dago, Bandung}

\subsubsection{Respondents Profile}

The education level of the head of the family in Mitra Dago is mostly undergraduated $(58 \%)$, as shown in Figure 2 . There is about $17 \%$ of family has a master degree and $5 \%$
JURNAL

MANAJEMEN

INDONESIA

Vol. 16 - No. 1

April 2016

Table 5

Willingness to Pay for

Femtocell Access

Table 6

Willingness to Pay for Femtocell Service

Table 7

Potential Market Segment for Femtocell Services 


\section{JURNAL}

MANAJEMEN

INDONESIA

Vol. 16 - No. 1

April 2016

Table 8

Mitra Dago User Segmentation of them has a doctoral degree. Most of the head of the familyaged is around 46-50 years old (35\%). The decision making in the family is mostly determined by Father (55\%). But in some families (30\%), each decision is taken jointly by the father and mother (30\%). Most of the family in Mitra Dago has 2-children (57\%). Some families have no-child (8.3\%), 1-child $(21.7 \%)$ and has 3 -children (13.3\%).

\subsubsection{Reliability Test}

Reliability test is applied to ensure consistency in measurement across time and objects. The reliability test result shows that the questionnaire is reliable to use. The Cronbach's Alpha( $\alpha$ ) value for 34 items of habit and attitude are bigger than 0.6 . The result showed that value of Cronbach Alpha is 0,728 .

\subsubsection{Segmentation}

Preliminary analysis starts with the cluster analysis classifies objects based on common characteristics among these objects. Used cluster analysis using K-Means Cluster that is processing the data all at once. This process begins with determining the number of clusters in advance, namely demographic factors grouped into 3 clusters based on income permonths, household expenditure for telephone and internet access, average call a day, and average internet access a day. We have got 3 cluster, there are Cluster 1 (Heavy user), Cluster 2 (Light User), and Cluster 3 (Moderate User). We can see from table 2. By using cluster analysis (KMeans Cluster analysis), the consumer can be segmented based on some common characteristics like income, telephone and internet access expenditure in amonth, average call in a day, and average internet access time in a day. Refer to the segmentation that defined in this study, the Mitra Dago consumer segmentation is shown in Table 9 below, they are: Cluster-1 as Heavy user, Cluster-2 as Light User, and Cluster-3 as Moderate User.

\begin{tabular}{cccc}
\hline Variable & Cluster 1 & Cluster 2 & Cluster 3 (ModerateUser) \\
& (High User) & (Light User) & \\
\hline Income monthly & Rp 5,000,000- Rp & Rp 2,000,000-Rp 5,000,000 & Rp 5,000,000-Rp \\
$10,000,000$ & & & 10,000,000 \\
$\begin{array}{c}\text { Household expenditure for } \\
\text { telephone and internet } \\
\text { access }\end{array}$ & Rp 500,500-Rp 750,000 & Rp250,000-Rp 500,000 & Rp 250,000-Rp 500,000 \\
$\begin{array}{c}\text { Average call a day } \\
\text { Average internet access }\end{array}$ & More than 4 times a day & More than 4 times a day & 3 to 4 times a day \\
\hline
\end{tabular}

\subsubsection{Habit and Attitude Towards Mobile Services}

In making a phone call,consumer of Mitra Dago usually does it between 12:00pm to 06:00pm (88\%). The others 5\% make a phone call between 06:00am-12:00pm, and 7\% make a call between06:00pm-12:00am. Family room is the best place for consumer in Mitra Dago to make a phone call in the house. While for internet access activity mostly donebetween 06:00am-12:00pm (33\%).

The study use MANOVA by using Pillai procedure, Wilks' Lambda, Hotelling and Roy's, it is found that there are 4-habit variables significantly differ the habit of consumer in using mobile services (Sig. < 0.05), they are about places to make a call (bedroom, leisure room), type of mobile services usage (chatting, browsing, social networking and email), handling the problem of a phone call (ask the destination to call back), handling the problem of phone call (complaint via call center), and handling the problem of mobile internet service (try other mobile phone).The four procedures using in the test represent that sig. $<0,05$. Pillai's (0.018), Wilks lambda (0.027), Hoteling (0.040) and Roy's (0.048). This study concludes that $\mathrm{Ho}$ is supported that there are differences in habit among heavy, moderate and light users when using mobile services or in other way it supports the hypothesis ( $\mathrm{H} 1$ is accepted). By using the same procedure, this study tests the attitude variables towards mobile services 
usage. The study finds that loyality to the operator, belief in consumer's operator, salesman influence, purchase intention and value expression differ the attitude of consumers in using mobile services ( $\mathrm{Sig}$. $<0.05$ ). Therefore this analysis support the hypothesis ( $\mathrm{H} 2$ is accepted).

\subsubsection{Femtocell Value and Services}

The factor analysis indicates that there are two different group factors affect the consumer to choose the femtocell service. In this study we categorize these two groups as:

- Group-1 (Core Value Group): Lower cost, Longer battery life, signal strength, and faster internet access

- Group-2 (Entertainment Group): Faster video/audio streaming

Therefore this result does not support the hypothesis ( $\mathrm{H} 3$ is rejected) that states better signal strength in the home is the most demanding factor to have Femtocell.

\begin{tabular}{lc}
\hline Signal strength & 0.870 \\
\hline Faster video/audio streaming & 0.990 \\
Cheaper call/data cost & 0.991 \\
Faster internet access using handphone & 0.852 \\
Longer battery & 0.991 \\
\hline
\end{tabular}

In analyzing customer preferences towards Femtocell services, this study runs the multidimensional scalling analysis and it shows that Family Alerts and Family Locator are the most interesting femtocell service for consumer. Therefore this result does support the hypothesis ( $\mathrm{H} 4$ is accepted) that states Family alerts as the most interesting Femtocell service for consumer.

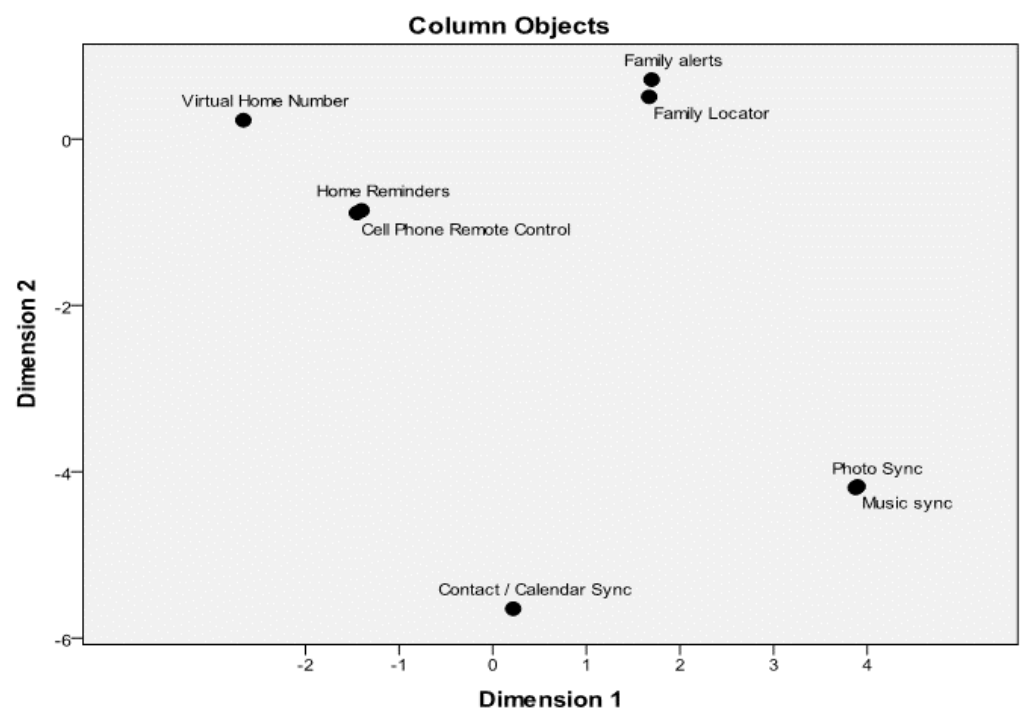

\subsubsection{Willingness to Pay for Femtocell Access and Services}

The descriptive analysis method in this study shows that most consumers (57\%) choose the range of Rp100,000-Rp125,000 as the price for femtocell access. About $35 \%$ of consumers choose the range price of $\mathrm{Rp} \mathrm{75,000}$ and $\mathrm{Rp} \mathrm{100,000}$ as the price for femtocell access
JURNAL

MANAJEMEN

INDONESIA

Vol. 16 - No. 1

April 2016

Table 9

Factorial Analysis of

Femtocell Value

Figure 2

Consumer Preferences

for Femtocell Service in

Mitra Dago 
JURNAL

MANAJEMEN

INDONESIA

Vol. 16 - No. 1

April 2016

Table 10

Willingness to Pay for

Femtocell Access

Table 11

Willingness to Pay for

Femtocell Service

Table 12

Potential Segment for

Femtocell

\begin{tabular}{ccc}
\hline & Frequency & Percentage (\%) \\
\hline Rp 50,000-Rp 75,000 & 5 & 8.3 \\
$\operatorname{Rp~75,000-Rp~100,000~}$ & 21 & 35 \\
$\operatorname{Rp~100,000-Rp~125,000~}$ & 34 & 56.7 \\
Total & 60 & 100 \\
\hline
\end{tabular}

Beside the femtocell access itself, this study also investigates the willingness to pay for each Femtocell service. Most consumers (50\%) choose the price range of Rp25,000 to Rp30,000 as the price for Femtocell service. There are about $25 \%$ of consumer choose the price between Rp30.000 and Rp35,000 for Femtocell service (see Table 11). One part of the results does support the hypothesis but another part (the Femtocell service willingness to pay) does not support the hypothesis. Therefore this study conclude that $\mathrm{H} 5$ is rejected that states Consumer has a willingness to pay between Rp100,000 - Rp 125,000 for Femtocell access, and between Rp20,000 - Rp25,000 for Femtocell service.

\begin{tabular}{ccc}
\hline & Frequency & Percentage (\%) \\
\hline Rp 20,000-Rp 25,000 & 2 & 3.3 \\
$\operatorname{Rp~25,000-Rp~30,000~}$ & 30 & 50 \\
$\operatorname{Rp~30,000-Rp~35,000~}$ & 15 & 25 \\
$\operatorname{Rp~35,000-Rp~40,000~}$ & 11 & 18.3 \\
$>$ Rp 40,000 & 2 & 3.3 \\
Total & 133 & 100 \\
\hline
\end{tabular}

\subsubsection{Potential Segment for Femtocell}

This study indicates that most of the consumers (90\%) are still uncertain about the Femtocell Value. Among the segments, Moderate user is the one who intents to have the femtocell servies in his/her house. Therefore this result does not support the hypothesis (H6 is rejected) that states Heavy users are the most profitable segment for Femtocell.

\begin{tabular}{llll}
\hline & Heavy User & Light User & Moderate User \\
\hline Agree to buy & 1 & 0 & 2 \\
Doubt & 3 & 26 & 28 \\
Total & 4 & 26 & 30 \\
\hline
\end{tabular}

\section{Conclusions And Implications}

This study investigates about femtocell opportunity in Indonesia telecommunication market and how the femtocell value fit to the habit and attitude of the mobile consumers. This scope of this study limited to two areas in Bandung, Buah BatuRegency and Mitra Dago-Antapani. All houses in thse areas have two-storey which may have problem on indoor coverage and capacity. The results of this study for Buah Batu Regency are $\mathrm{H} 1$ and $\mathrm{H} 2$ are supported while the others are rejected. The results for Mitra Dago are $\mathrm{H} 1, \mathrm{H} 2$ and $\mathrm{H} 4$ are supported while the others are rejected.

The results of research in Buah Batu Regency show that (1) there is attitude differences among heavy, moderate and light users when using mobile services, (2)there is habit differences among heavy, moderate and light users when using mobile services (3)high Speed 
internet access in the home is factor that encourages customers attracted to the Femtocell, (4)home reminder and Family locator are the most interest Femtocell service, (5) Customers are willingness to pay between $\mathrm{Rp} \mathrm{50,000} \mathrm{-} \mathrm{Rp} \mathrm{75,000} \mathrm{for} \mathrm{Femtocell} \mathrm{benefit,} \mathrm{and} \mathrm{between}$ Rp Rp 25,000 - Rp 30,000 for Femtocell service (6)Moderate users are the most profitable segments for Femtocell. On the other hand, the results of research in Mitra Dago show that: (1)there is attitude differences among heavy, moderate and light users when using mobile service, (2)there is habit differences among heavy, moderate and light users when using mobile services, (3) access data more cheaper and handphone battery more durableis factor that encourages customers attracted to the Femtocell, (4) family alerts and Family locator are the most interest Femtocell service, (5)customers are willingness to pay between $\mathrm{Rp}$ 100,000 - Rp 75,000 for Femtocell benefit, and between Rp Rp 25,000 - Rp 30,000 for Femtocell service, (6) Moderate users are the most profitable segments for Femtocell.

Consumers are still uncertain about femtocell value and benefit therefore service provider/operator needs to communicate about the femtocell value first to the market. Service provider can run the free trial activity with some moderate users and communicate the result or testimony to other segment

\section{References}

Bagozzi, Richard P. (2006). Explaining Consumer Behavior and Consumer Action: From Fragmentation to Unity. Seoul Journal of Business, vol 12, no 2.

Souiden, N. and Mariam Diagne (2009). Canadian and French men's consumption of cosmetics: a comparison of their attitudes and motivation. Journal of Consumer Marketing, Vol 26, pp. 97-109.

Jalalkamali, M., DavoudNikbin (2010). The effects of motivation on purchase decision. Interdisciplinary journal of Contemporary Research In Business, Vol 2 no 8.

Kim, Y. Hee(2008). Exploring consumers' adoption of highly technological fashion products. Journal of Fashion Marketing and Management, Vol. 14 No. 2.

Lindquist, J.D, M. Joseph Sirgy. Shopper, Buyer, And Consumer Behavior, Atomic Dog, a part of Cengage Learning, United States of America, 2009. 
JURNAL

MANAJEMEN

INDONESIA

Vol. 16 - No. 1

April 2016

Jurnal Manajemen Indonesia 